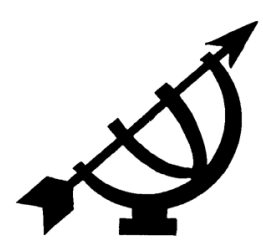

\title{
Life- and worldview: development and transformation - the case of the Lamba of the Masaiti region in Zambia
}

J. Compion, J.L. van der Walt, H.J. Steyn \& C.C. Wolhuter

Department of Comparative Education

Potchefstroom Campus

North-West University

POTCHEFSTROOM

E-mail: jannielise2@gmail.com hannesv290@gmail.com

hennie.steyn@nwu.ac.za

charl.wolhuter@nwu.ac.za

\begin{abstract}
Life- and worldview: development and transformation the case of the Lamba of the Masaiti region in Zambia

This article reports on a case study regarding the development and educational transformation of a subgroup of the Lamba living in the Masaiti region of the Copper Belt Province of Zambia, where the Foundation for Cross-Cultural Education in Zambia (FCE) has been serving for the past thirteen years. It was concluded that the current life- and worldview of a community such as the one living in the Masaiti region can be transformed to a truly Christ-centred life- and worldview by firstly taking cognisance of how the community currently expresses itself in terms of each of the universals or components of a lifeand worldview, and secondly by subjecting each of those universals or components to a process of life- and worldview transformation. It was furthermore found that life- and worldview transformation should be seen as a prerequisite for the developmental transformation of such communities.
\end{abstract}




\section{Opsomming}

\section{Lewens- en werklikheidsvisie: ontwikkeling en transformasie - 'n gevallestudie oor die Lamba woonagtig in die Masaiti- streek van Zambië}

Hierdie artikel berig oor 'n gevallestudie aangaande die ontwikkeling en die onderwyskundige transformasie van 'n subgroep van die Lamba, woonagtig in die Masaiti-streek van die Koperbeltprovinsie van Zambië. Die Foundation for Cross-Cultural Education in Zambië (FCE) is reeds die afgelope dertien jaar werksaam onder die mense in hierdie gebied. Daar is tot die gevolgtrekking gekom dat die huidige lewens- en werklikheidsvisie van 'n gemeenskap soos dié van die Masaiti-streek getransformeer sal kan word tot 'n ware Christus-gesentreerde lewens- en werklikheidsvisie. Dit kan gedoen word deur eerstens in ag te neem hoe die gemeenskap homself tans tot uitdrukking bring in terme van elkeen van die universaliteite of komponente van 'n lewens- en werklikheidsvisie, en tweedens deur elkeen van hierdie universaliteite of komponente te onderwerp aan 'n proses van lewens- en werklikheidsbeskouingstransformasie. Daar is ook tot die gevolgtrekking gekom dat lewens- en werklikheidsvisietransformasie beskou moet word as 'n voorvereiste vir die ontwikkelingstransformasie van sodanige gemeenskappe.

\section{Introduction}

This article reports on a case study regarding the development and educational transformation of a subgroup of the Lamba living in the Masaiti region of the Copper Belt Province of Zambia. The Lamba comprises a total of approximately 300000 people spread over the Masaiti district of Zambia as well as the Katanga district of the Democratic Republic of the Congo. They are scattered all over this area in small villages, each under a headman. The villages consist of 20 to 30 huts (family groups) each. The land of the Lamba is currently under the traditional leadership of Paramount Chief Mushili. The Lamba of the Masaiti region (henceforth referred to as the Masaiti community or people) is a developing community of approximately 4000 people in a rural area spread over approximately 100 small villages and a host of small scale subsistence farms and a few commercial farms (Lisati, 2006:7). The social organisation of the Lamba is interwoven with their religious and spiritual conceptions (Doke, 1970:27, 50).

The Foundation for Cross-Cultural Education in Zambia (FCE) has been serving in the Masaiti community for the past thirteen years. In 
this time, the FCE developed a mini-education system for developing countries and communities in Africa, and specifically for the Masaiti community. The FCE is an international, non-denominational, non-racial and non-profit Christian organisation. Its focus is on discipling and equipping disadvantaged rural and hard to reach communities with knowledge, skills and biblical values that will lead to community transformation. In the Masaiti community, the FCE established a Training College, a Community Training Centre and several activity centres as part of its mini-education model.

In 2007, the Ministry of Education of Zambia's Directorate of Planning and Information (Zambia, 2007) expressed concern about the future of education in developing communities in Zambia, and was convinced that many parents did not make adequate use of the opportunities available for the education of their children. It summarises the educational challenges as follows:

The rural phenomenon of erratic participation and non-utilization of facilities indicate (sic) low levels of explicit demands. Family dependence on the economic activities of children, the impact of AIDS on family organization and income, the increasing number of orphans, the growing number of childheaded households and levels of poverty that preclude any school-related outlays, are among circumstances that have reduced explicit demand for education or that may require that the explicit demand be met in imaginative and novel ways. (Zambia, 2007:15.)

The FCE mini-educational model is an attempt to meet the challenge of finding an innovative solution to the problem. The purpose of the FCE education model is to train students to:

- work as facilitators in community training centres in disadvantaged communities;

- establish children's activity centres and schools at FCE training centres; and

- motivate and train people to participate in the upliftment of specific communities (Highway chronicles, 2005:17).

Based on the study reported below, it was concluded that the current life- and worldview of a community such as the one living in the Masaiti district can be transformed to a justifiable Christ-centred lifeand worldview by firstly taking cognisance of how the community currently expresses itself in terms of each of the universals or components of a life- and worldview, and secondly by subjecting each of 
those universals or components to a process of life- and worldview transformation. It was furthermore found that life- and worldview transformation should be seen as a prerequisite for the developmental transformation of such communities. The remainder of this article will offer evidence in support of this two-step claim. Firstly the applied methodology will be outlined, and the anatomy of a life- and worldview will be discussed to show how a life- and worldview can be transformed to Christ-centredness. This will be followed by arguments in support of the thesis that life- and worldview transformation should be seen as a precondition for community transformation.

\section{Methodology}

The investigation focused on the transformation of developing communities in general and on the Masaiti community in particular, as well as on how the FCE mini-education system might contribute to the transformation of such a community through life- and worldview transformation. Based on a Christ-centred/biblical view of reality, life, the human being and communal life, the investigation proceeded through several phases. The first step was to analyse the different educational levels embodied by the FCE model. Secondly a general analysis of the anatomy of life- and worldviews followed. This, in turn, was followed by an examination of philosophical (including lifeand worldview) transformation. All of these insights were then applied to the traditional (pre-1919) and current life- and worldviews of the Lamba and more specifically to the more recent process of their life- and worldview transformation. This sequence is also followed in the rest of the article. The data was acquired from literature and conversations and interviews with leaders of the Masaiti community, as well as conversations and interviews with other knowledgeable community workers. The semi-structured interviews were audio-taped, transcribed and relevant individual contributions were integrated into the reporting. The preparation, analysis, structuring and interpreting of the data was aimed at identifying the recent areas of transformation of the Masaiti developing community.

\section{Anatomy of a life- and worldview}

\subsection{Introductory remarks}

Life- and worldviews shape our understanding of ourselves and our world (Bufford, 2007:293). These views are formed by a complexity of influences including education, geography, economic organisation and historical events. A life- and worldview and its related value and attitude systems change constantly, but usually at a very slow pace, 
measurable in decades or generations (Walsh \& Middleton, 1984:171). According to Bufford (2007:293), life- and worldviews are developed very early in life. It is only later that one may learn to articulate and talk about them as one begins to recognise that others hold different life- and worldviews.

Educational practices stem from policies that are derived from a particular concept of development, which is in turn rooted in a lifeand worldview. Van Brummelen (1988:86) is convinced that effective educational communities have teams of teachers whose life- and worldview determines the purpose of schooling and the nature of learning. A life- and worldview is made up of different kinds of beliefs and components. These key beliefs and components are as follows.

\subsection{The universals/components of a life- and worldview}

\subsubsection{Faith commitment and ethos}

One's faith commitment and ethos set the contours of one's life- and worldview and give content and shape to all the other life- and worldview universals (i.e. components of the life- and worldview). They shape one's vision for a way of life. One's faith precedes a lifeand worldview, without which human life simply cannot go on (Walsh \& Middleton, 1984:35; Bufford, 2007:293). This ethos embodies the values which inform and direct the logic and the assumptions that shape life- and worldview universals (Craffert, 1997:202; Karecki, 1998:317).

A person's faith commitment is revealed in the answers given to the following four basic life questions (Dreeckmeier, 2005:11):

- Who am I? (Or, what is the nature and significance of human beings?)

- Where am I? (What sort of world or universe do we live in?)

- What is wrong with the situation in which we find ourselves? (How can we account for the brokenness and distortion of this world?)

- What is the remedy? (How can we eradicate this brokenness?)

The way we think about these questions shapes our vision of life and determines the way we act in this life. Faith commitments are expressed in the fundamental principles and ideas of a culture, the story, ideals and vision it accepts as true (Miller, 1998:38, 47). According to Nash (1992:168), belief in the rational capacities of the 
human being is not exempted from being a belief in itself. Life- and worldview perspectives provide the foundation for development in a community or society. Van der Walt (1991:17) and Cunningham and Fortosis (1987:14) conclude that there is thus no life-conceptual neutral ground, because everyone believes in something (cf. also Gray, 2009:12). Convictions about the basic makeup of the world and how it works are held consciously as well as un- or subconsciously in faith in the form of a set of assumptions, called a lifeand worldview (Miller, 1998:38, 47).

\subsubsection{Life- and worldview universals}

According to Nash (1992:26-30), Craffert (1997:205-207) and Van der Walt (2001:13), a well-rounded life- and worldview should at least include the following universals or components, namely convictions about God (who is the ultimate being?), morality (what is good?), knowledge (what is true?), humankind (what is the human being?) and reality/nature (what is real?). Life- and worldview analyses demonstrate that worldviews are imbedded, among others, in a relationship with the physical and social environment. Harrison (1985:6) and Craffert (1997:208-209) mention three worldview factors of crucial importance for development in a community.

- The worldview's time focus - past, present or future

- The extent to which the worldview encourages rationality

- The concepts of equality and authority it propagates

For trainers in a particular training centre to proceed adequately with life- and worldview transformation in the surrounding community, it is important to understand the beliefs that constitute the life- and worldview of the community. Van der Walt (2001:17) is convinced that only a radical biblical life- and worldview can provide the necessary new vision and direction people are looking for today, because it indicates people's real place in God's creation. It also calls people to an all-encompassing task of service in this world. The transformation of a life- and worldview or a philosophy entails the act of critically "taking captive" (2 Cor. 10:5) animist or secular thought. This can only be accomplished responsibly by reinterpreting it and transforming it on the basis of biblical perspectives (Klapwijk, 1987:110).

\section{Life- and worldview transformation}

According to Klapwijk (1987:138), life- and worldview transformation refers to the "critical assessment, selection, and appropriation of 
existing intellectual goods in such a way that their incorporation into a Christian worldview means a restructuring and redirecting of their content, a redefining of their scope or meaning". The idea of transformational philosophy presupposes a recognisable, distinctively Christ-centred or reformational position. Fowler (2001:130) provides a succinct summary of both the challenge and the essence of such transformation.

The challenge to a transformational (in casu) education comes to us in the words of the Apostle written to the Romans (12:1, 2). It offers just two possibilities for those who have experienced the mercies of God in Jesus Christ. One is to live in conformity to 'this world', adopting the patterns of living that are considered to be normal by 'this world'. The other is a life that gladly serves God with a mind-renewing transformation in all that we do. There is no middle course.

Those who transform should find their position in Christ, and take non-christian thought into captivity for Christ. Reformational philosophy is, therefore, at the same time transformational philosophy (Klapwijk, 1986:105).

Christians are called to sanctify all of life, including the life of culture and society. If Christians fail to do so, then the encounter between christian belief and worldly philosophy brings about the opposite situation, that is Christians being brought under the influence of the worldly climate of thought. That is also a kind of transformation, but then in the opposite, anti-normative direction - an inverse transformation. One could also speak of inverse transformation when the sanctification of culture stagnates to the extent that a worldly way of thought creeps into a previously christianised society (Klapwijk, 1986:147).

According to Klapwijk et al. (1991:249), knowledge and wisdom will have to be taken up into the service of the Lord and integrated into a God-directed view of life. It is therefore necessary for the christian thinker to refine the ideas he/she borrows from others and to detach them from their ideological context (Klapwijk et al., 1991:146, 188). Transformation refers to a radical change in all spheres of a person's life. It begins on the inside, at the level of beliefs and values, and moves outward to embrace behaviour. The gospel thus becomes God's total response to man's total need (Miller, 1998:129132).

Development transformation in itself is a dynamic process. It begins with the proclamation of the gospel for the purpose of breaking the 
power of sin and death. It then involves the exchange of lies for the truth (repentance) and death for life (regeneration). God intends that whole cultures be reformed. Discipling a community therefore implies laying kingdom principles and a Christ-centred life- and worldview as the new founding order or ethos of a culture. It is the renewal of the mind by instilling in it the mind of Christ (Miller, 1998:67).

Different life- and worldviews lead to ideas that have consequences for the transformational development and education of developing communities (Van Niekerk, 1993:5-11). The key to transformation, therefore, seems to lie in the mindset or life- and worldviews of people, in which their education plays no minor role. The spiritual realm impacts the physical realm at the level of culture. The life- and worldviews of people do not only determine how they see the world, but more importantly determine the kind of societies, communities and education systems that they build. Life- and worldviews and the resulting cultures have an effect on transformational development (Miller, 1998:33-49).

According to Dreeckmeier (2005:14), life- and worldviews can be categorised according to the following continuum:

\begin{tabular}{|c|c|c|}
\hline Animism & Christ-centred & Secularism \\
\hline$\longleftarrow$ & & $\longrightarrow$ \\
\hline $\begin{array}{l}\text { Ultimate reality is } \\
\text { spiritual }\end{array}$ & $\begin{array}{l}\text { Ultimate reality is } \\
\text { personal }\end{array}$ & $\begin{array}{l}\text { Ultimate reality is } \\
\text { physical }\end{array}$ \\
\hline
\end{tabular}

Generally speaking, the traditional Lamba life- and worldview can be located in the left column of this table, and the current western secular life- and worldview in the column on the right. The life- and worldview universals or components embody convictions about God and morality (Dien, 1997:345-348), knowledge, humankind and reality/nature. It shall now be demonstrated how each of the universals can and should be transformed for the purpose of effecting a total life- and worldview transformation towards a Christ-centred/reformational/biblical perspective. In each case, we outline the Lamba living in the Masaiti region's traditional (syncretistic) view and then demonstrate how it can be transformed. 


\section{The current life- and worldview of the Masaiti community}

\subsection{View of God and of morality}

The Lamba traditionally believe that man and nature were made by some spiritual being (high god) known as Lesa who came to the earth in the beginning under the name of Luchyele. He is invisible, manifests himself in long dead ancestors (reincarnated) and in the form of trees, snakes, rocks and so on. God is spirit and lives in heaven and does not relate to people (Doke, 1931; 1970:31, 225). After birth, babies receive charms or tattoos in order to protect them from the spirits. A spirit returns to the superior spirit (Lesa) who allows it to hover in the sky. The Lamba believe in spiritual healing by ancestors, in good spirits protecting people from dangers like witchcraft, and bad spirits that cause people to become mad and eventually die. Spiritual powers exist as demons or human manifestations like Chipimpi. Some regard John the Baptist's head as Chipimpi. Spiritual powers are strong. Like that of a god, they can kill, bring rain, cause illness, love people who obey, and hate those who displease them (FCE College, 2009).

For the animist, God is impersonal. The human being is controlled by spiritual forces, whether ancestors or ghosts, gods or spirits, witchcraft or sorcery, curses or the evil eye. These forces attempt to manipulate the spiritual forces of God's world to discover its secrets in the hope of personal benefit through sacrifices. These motivations are alien to the mind of God, according to Van Rheenen (1991:511). When confronted with evil, animists typically ask questions like: "Who has caused this affliction to come upon us?" Animism denies the sacredness and significance of human life (Van Rheenen, 2003:1-7). While denying the sacredness of life, secularism affirms, without reason, that man is good, and that right and wrong should be gauged situationally (Miller, 1998:184).

The Christ-centred view is relational. It sees God as the triune, almighty Creator and Sustainer of the universe (Dreeckmeier, 2005: 34). Morals are seen as expressions of the character of God (or the idol) that one serves (Miller, 1998:129-132). Christians believe that evil exists by invitation on personal, natural, and moral levels. Wolsterstorff (1980:34) summarises the ultimate Christ-centred moral law as: "You should love your neighbour as yourself".

The way the Lamba relate to God determines their morality, values and behaviour for development. One cannot have physical develop- 
ment without moral development, because the universe is ultimately moral. The degree to which this insight into the transformation of mind and ethos is mastered, determines to which extent the Masaiti community is encouraged to proceed on the road of community development and transformation. According to Colsen (1999:16), no transgression of moral law is without painful consequences. A society should therefore identify evil in order to overcome evil. The more lies that remain imbedded in a culture, the more hostile its social environment will be to development (Miller, 1998:176).

The human conscience is a critical part of moral law. Through the Holy Spirit, the Masaiti community should fortify their personal lives against moral evil, challenge the dominion of personal evil, and fight against the ravages of physical evil. This can be effected through feeding the hungry, clothing the naked and setting the oppressed free (Miller, 1998:129-132). An education system that strives to impact the Masaiti community will have to take a strong stance on Christ-centred morality.

\subsection{View of knowledge}

The view of knowledge does more to shape development, prosperity or poverty than does the physical environment. This applies if a community's worldview encourages the belief that

- humans desire to know and understand the world around them; and

- the universe operates according to a pattern of created laws.

When these factors are in place, it will impart knowledge, skills and attitudes that are linked to ideas of progress and transformational development (Harrison, 1985:6).

According to Doke $(1931 ; 1970: 148)$, the Lamba traditionally believe(d) that everyone dies because of witchcraft. They append charms to the body of the deceased so that a good spirit will follow the bad spirit that caused the death. Spirits supposedly control life, death, curses and blessings and cause disease, hunger, divorce, barrenness and blindness if angered. When someone falls ill, the umalaye (traditional healer) is sent to diagnose not the illness, but its cause and to prescribe treatment for its elimination (Doke, 1970: 177). After recent visits to areas in the community, FCE community workers reported that some people accepted medicine from the hospital, but also performed rites with medicine to pacify the spirits. 
Animists deify and worship nature and do not regard it as an object to be studied. They believe that knowledge is unknowable, hidden or attained through states of mystical consciousness (Dreeckmeier, 2005:34). Secularism denies the existence of absolute truth, and holds that truth, if it exists, remains unknowable. Knowledge according to secularists is what human senses can perceive and can only be gleaned through the scientific method (Ward, 2005:510; Miller, 1998:68, 117, 229).

The Christ-centred view holds that man lives in an intelligible universe where truth is real, knowable, and humans are fully justified in developing their god-given spirit of discovery and learning. God's natural laws reflect his will. Truth exists, because He exists and has revealed it by his works and words. The mind of Christ, a preexisting intelligence which lived before human beings, provides the foundation for human reason. God has given man the ability to discover the design behind nature (science) and to apply these laws (technology) in attacking the ravages of natural evil, the "thorns and thistles" (Miller, 1998:100, 209; Nature Publishing Group, 2007:761). According to Van Brummelen (1988:89), this true knowledge and empirical evidence, becomes the "ladder" by which man's faith in God the Creator "climbs higher and higher".

The view of knowledge that the teacher and community worker hold will determine the type of programme they implement in the Masaiti community. Transformational development is based on knowledge and attitudes towards learning that ultimately reflect one's behaviour, speech, family and handiwork. Educationists' outlook will determine which educational programme and resources are chosen for unfolding this reality to the Masaiti community (Mechielsen, 1980: 41). The Lamba of the Masaiti region must be given the opportunity to know and study the world around them and to develop and utilise their god-given spirit of discovery.

\subsection{View of the human being}

Educational systems and policies bear the unmistakable imprint of thoughts in the way one views others and interacts with them (Van Brummelen, 1988:87). At birth, or soon thereafter, many children in the Masaiti community receive the so-called "spirit name" of a reincarnated spirit of a deceased relative. Whenever a married person dies, the spouse secures life by marrying someone of the same family (Doke, 1931; 1970:146, 193). If a new baby is born at this time, the deceased's name is given to the baby so that the person may continue living in the baby. 
According to the Lamba, people are neither good nor bad; their deeds make them good or bad. Some believe that dead people can see, hear, walk and speak and therefore get hungry, tired, lonely, angry and frightened (FCE College, 2009).

The Christ-centred life- and worldview holds that male and female do not exist in isolation and are created by God as relational beings. Humanity was created by/through the Word of God (Gen. 1 \& 2). Even in unbelief man does not escape this God-relationship as the fundamental condition for his/her existence. The Christ-centred view purports that the shortcomings in the human being's present life is due to sin. Christians know that their sinful position is not the final word about man, but that God's redemption in Christ is. This calls us to an educational practice that is integral to a whole and undivided life where Christ is Lord (Fowler, 1987:1-5).

\subsubsection{Individualism and collectivism}

For the animist, self-identity is only realised through communal identity (Chike, 2008:224). The human person is not an autonomous individual, but a social being whose personal identity is inseparable from that of the community (Edgell, 2007:53; O'Donovan, 1992:4-5). According to Harisson (1985:8), the rigour of an effective ethical system will shape attitudes of freedom and justice which are central to several major development issues. If the members of a society expect injustice, the ideas of cooperation, stability and continuity will be undermined. Corruption and nepotism will be encouraged. Authoritarianism will negatively affect the growth of individuals and society. Mistrust in a society stunts the creation of public institutions (Harrison, 1985:8).

The secularist believes man to be the centre of the universe. The human being is tempered by the belief that reality is impersonal and purely physical. What is real in society is the individual. She/he is regarded as the seat of meaning and authority.

The above-mentioned individualist and collectivist views contradict the Christ-centred view that individuals in a society need to be interdependent in social responsibilities and interactions. A learning community should thus not be rooted in the greed of individualism or the envy of collectivism, but in contentment, which comes when people relate properly to God. The Masaiti community needs to develop trust that extends beyond the family, both in economic and educational development (Van der Walt, 1991:64, 66). 


\subsubsection{Human beings' relation to economics}

In the animist context, personal initiative and independent action unknown to ancestors are discouraged, for they might arouse envy. From a Christ-centred view stewardship means to administer households (the Greek oikonomia, the root of the word "economics", literally meaning "household"); to "fill the earth with the knowledge of the Lord". Here economics is stewardship; the human being is placed in a position to exercise dominion over nature, to cultivate and develop it (Miller \& Blignaut, 2004:4-10).

Both servanthood and authority are central to our humanness. We may not rule the earth as we please, because we do not own God's kingdom (Walsh \& Middleton, 1984:59, 157). Secular societies have reduced people made in his image to consumers and producers of the products of industrial and post-industrial society. Work is no longer a sacred task. According to the Christ-centred view, the Masaiti community should be placed in a position to exercise stewardship with servanthood and obtain a balanced view of development and progress.

\subsection{View of reality}

\subsubsection{General principles}

The Lamba believe in a spiritual reality; their concept of material existence is very vague (Doke, 1970:222-228; Chike, 2008:222). The physical world is just an illusion; it is animated by spirits (Van Rheenen, 1991:15-30). The imipashi (spirits) were originally left by Lesa to care for and help people as earthly beings. Traditionally the Lamba strongly believe in witchcraft (ubufwiti) and fear it. Previously, every death was accredited to witchcraft (Doke, 1970:302-305).

There is also a dynamistic belief in ubwanga (spiritual weapon) where certain preparations, charms, medicines, actions and words can bring protection (Holmgren, 1998:21). To keep the spirits happy and to protect the harvest, charms are still buried in fields (FCE College, 2009).

\subsubsection{View of time}

According to biblical standards, time can be wasted, but animists believe that time is without limit and value, and therefore cannot be wasted. The animist is enslaved to the past, unable to see present opportunities or to plan for the future. This outlook has negative consequences for economic development. Secularists say that time is money. Their goal is not quality relationships, but material affluence 
(Miller, 1998:186, 248-274; Chike, 2008:225). With this warped secular view of time, change becomes a hollow substitute for progress, devoid of moral purpose and growth. True growth/progress is the synthesis of change and continuity. Where there is no continuity there is no growth or progress.

\subsubsection{The use of land}

Animists regard themselves as inseparable from the land - it is a friend to pass on to their descendents. It provides food, security and shelter and is a source of identity and self-respect (Walsh \& Middleton, 1984:27-28). According to the secular view land can, like food and clothing, be owned, bought, sold and exploited as a market commodity.

The transformational development of the Masaiti community is about discovering and exploring God's world, and not merely helping people to survive. It involves utilising resources, not redistributing scarce ones. The economist Schumacher (as quoted in Miller, 1998:148) states, "Study how society uses its land, and you can come to pretty reliable conclusions as to what its future will be". We may indeed ask why so many Masaiti land owners are still caught up in poverty.

\subsubsection{Poverty}

Miller (1998:67) alleges that physical poverty is rooted in a poverty mindset, a set of ideas held corporately that produce certain sets of behaviour. Such behaviour can be institutionalised into the laws and structures of society (Silvoso, 2007:116). Brookes (quoted in Miller, 1998:115) states that wealth is not physical, but metaphysical. Miller and Scott (2005:31-38) assert that those with a poverty mindset see the world through poverty spectacles. In animism, man is dominated by nature, and a fatalistic mindset often affects social responsibilities, which are viewed as omnipotent (Van Rheenen, 1991:5155). People and their actions tend to say, "I am poor and always will be poor", or "I am poor because others made me poor". An animist believes him-/herself to be a victim of external circumstances like exploitation, oppression, and many nameless powers. "The bus left me behind" - not "I was too late for the bus" (Scarborough, 1999:3).

Van der Walt $(1991: 14,17-18)$ avers that a poverty mindset can also affect Christians, in their case often because of Greek dichotomous thinking which divides the universe into the spiritual realm, viewed as sacred, and the physical, viewed as profane. Their lives are di- 
vided into compartments: the "religious" (what they do when attending church or Bible study) and the "secular" (their jobs, recreation and education). In contrast, a radical Christ-centred view encompasses all of life and Christ's kingship is acknowledged in all cultural activities (Walsh \& Middleton, 1984:64).

Every culture, according to Walsh and Middleton (1984:39, 54), has its own set of blinkers that prohibit people from seeing reality in totality. Teachers and community workers therefore need to explore the cultural realities that shape the Masaiti community's thinking and actions. The crucial question is whether the life- and worldview of the Masaiti community is consistent with reality, otherwise it will resist the biblical vision as well as every effort to bring about community transformation.

\subsubsection{Labour}

For animists work is a curse and a survival tool (Miller \& Blignaut, 2004:3). They believe that prosperity depends on manipulating and propitiating envious spirits and people (Scarborough, 1999:2). According to Batchelor (1993:1-12), government assistance for the poor is counterproductive, because it discourages work incentive.

Work, according to a Christ-centred view, is not a separate but an integral part of life. God is at work in the world, therefore He calls people to participate in building his kingdom through work (Walsh \& Middleton, 1984:155, 164). Secularists do not have vocations, merely "jobs" viewed in economic terms. Work becomes a means to an end, but a vocation (calling) forces the eyes of the faithful towards the future (Harrison, 1985:6).

Since the life- and worldview of the Masaiti community explains reality only through spiritual forces that demand obeisance from humans, it tends to nullify the need for reason, planning ahead, working hard, wise use of land and progress in education. Transformation of their attitude towards work will, however, bring about a change in their future perspective on life, which in turn will become a stimulus for community development.

\section{The transformation of the life-view of the Masaiti community}

A positive degree of transformational change has already taken place among the people of the Masaiti community (Els, 2009; Holmgren, 2009; Mushili, 2009; Pensilu, 2009). Despite this, many en- 
trenched views and beliefs have yet to be traded in for full and lasting transformational development in the community. According to Paramount Chief Mushili (2009), the Lamba view of God and morality has indeed undergone a measure of change. Witchcraft currently does not have as strong an influence on the Lamba as in the past. Approximately $75 \%$ of the Masaiti community still believe in, and are influenced by spiritual powers and believe God to be invisible and impersonal. The church has brought a substantial amount of freedom to the area, but religious denominationalism has also caused division within villages. In the process, both animist and western-type secular thinking have become integrated with Christianity. Though people have become more aware of the living God, and place less emphasis on traditional gods like Chipimpi, what is considered wrong in the community is generally still determined by the community (not God, the Bible or even other individuals). Some people honour the Word of God as the final authority on moral issues. Approximately $75 \%$ to $85 \%$ of the Masaiti community go to church, but are now affected by a dualistic (syncretistic) worldview. For instance, some church people still believe that God gives spirits charge over life, death, curses and blessings (Els, 2009).

Transformation of the Masaiti community's view of the human being is signified by increased freedom to express personal views, showing less respect for authority, and a growing tendency to follow an undisciplined lifestyle (Els, 2009). Despite this, Chief Mushili (2009) attests to a positive change in the behaviour of the Lamba in that stronger relationships have been formed among the people as the affects of fear of witchcraft wear off. Christianity has brought about some specific changes in cleansing practices and in the initiation rites of girls. Some are still jealous when others do well or take the initiative, but in Pensilu's (2009) view it is happening less today than in the past, because of people's desire to develop. Generally, in the past, people showed greater cooperation. Nowadays there is a stronger move towards individualism where people want to "do their own thing". The reason for this might be the influence of the western-type state education system (schools) and the media.

The way people view the concept of time, shows that the past is still disproportionably important to them. This may result in a lack of purpose. Others have come to realise that time is valuable.

Trust in spirits is still part of the Lamba's reality. There is consensus that poverty in the area is a direct result of the fear of witchcraft: "Hard work can lead you to the grave". People tend not to utilise their god-given resources and abilities, and rather wait for external 
help (in the form of foreign aid). Theft has also increased over the last two decades. All of this impedes the process of development among the majority of the Masaiti community. Because of witchcraft, people are often afraid to reveal the identity of thieves. Many members of the Masaiti community work hard in their struggle for survival, but many others are affected by laziness and a spirit of hopelessness (Pensilu, 2009). Hard work does not always show the desired results. The people of the Masaiti region generally concede that physical development has occurred in the area due to the provision of more schools, clinics, church buildings and more food in recent years. Land is still seen as a form of security. The saying among the local people is still that land is "like the breast of a mother"; one keeps on feeding from it (Pensilu, 2009). Recent years have also been characterised by land issues and skirmishes between villages (Mushili, 2009).

Inverse life- and worldview transformation has unfortunately also occurred among the Masaiti people. Many seem to adhere to the western-type secular view that the human being is in charge of his/her own destiny, and that the individual is more important than the community. A notion has also been developing that if people have jobs all their problems will disappear. People have become more materialistic, and money has become a bone of contention. According to Holmgren (2009), a "receiving" mindset has taken hold, and family structures have been breaking down as a result of higher rates of immorality, especially due to alcohol abuse. Living conditions have also been affected by a lack of food production. Natural resources are becoming depleted and a greater dependency on chemical resources has taken root. Cultural survival skills have been lost because of the already mentioned dependency on foreign aid (Els, 2009).

The transformational role that the FCE has played in the Masaiti community is significant. Over the last thirteen years there has been a strong emphasis on the education of children through evangelisation, outreach and ministry, the establishment and implementation of child stimulation programmes, and initiatives such as Christ-centred school education (Chibuye, 2010). All of these initiatives have led to improved behaviour among village children. They play more instead of sitting around passively, their spontaneous singing is often heard, and so forth. As far as food production is concerned, an improvement is evidenced by the decrease in hunger in many villages. Planning has also improved. Skills training has meaningfully impacted the community. There is also a greater unity among the churches in 
this area. The FCE seems to have played a significant role in the training and bringing together of pastors from different denominations through the establishment of a pastors' fellowship. There is also an improvement in the mindset of the people - it has become more biblical. The Masaiti community seems to study the Word more systematically than ever before (FCE, 2005).

\section{Discussion}

Over the past 100 years or so, since a christian life- and worldview was introduced by missionaries to this area, many changes have taken place among the people of the Masaiti region. The gospel has been bringing light to them. Fear of witchcraft practices has been dissipating. Many physical changes have also occurred in the area. People nowadays view things differently. However, when it comes to the life- and worldview - the deep questions about who God is, who the human being is, how we should look at nature - many old beliefs still remain untransformed. A total belief system change that would culminate in total cultural transformation is still to take effect. Changes in practice will result in lifestyle changes. The people of the Masaiti region have unfortunately also been developing a (typical western-type secular humanist) divide between belief and behaviour. They have not yet reached the stage where belief dominates the core of their existence and resultantly becomes personalised into a relationship of trust, a condition where a person's values will change and behavioural acts will become a reflection of that trust (Holmgren, 1989:17).

The life- and worldview transformation of the Masaiti community demands that kingdom principles and a Christ-centred life- and worldview be accepted as the new founding order or ethos of the culture. These should not be a mere spiritual layer of Christianity laid over an animistic and secular life- and worldview, that is to say syncretism. As stated above, transformation refers to a radical change in all spheres of a person's life (Van der Walt, 1991:14). Transformation begins on the inside, at the level of beliefs and values, and then moves outward to embrace behaviour and mindset. The transformation of animistic, secular and/or syncretistic thought can only be accomplished responsibly through reinterpretation within the context of a Christ-centred life- and worldview. Effective educational communities have teams of teachers whose life- and worldviews determine the purpose of schooling and the nature of learning.

The FCE mini-education system seems to be contributing towards the transformation of the Masaiti community through the Christ- 
centred life- and worldview that it propounds. This work is presently being channelled through its Training College, its Community Training Centre and the activity centres among the people of the Masaiti community. Despite the work done by the FCE, the life- and worldview of the people in the Masaiti region needs further, significant, and mind-renewing transformation in order for new perceptions of reality and community development to be brought forth (cf. Karecki, 1998:316).

\section{Conclusion and recommendations}

The discussion above has vindicated the proposition presented in Section 2 that the current syncretistic life- and worldview of a community such as that of the Masaiti region of Zambia can indeed be transformed to a truly Christ-centred life- and worldview. This can be done by taking cognisance of how that community currently expresses itself in terms of each of the universals or components of a life- and worldview, and then taking each of those universals/ components through a process of life- and worldview transformation.

At present, reality for the Masaiti community is still mostly spiritual. For many, the real world is still the unseen; the physical is still only an illusion, and spirits still animate everything. Truth is still hidden, irrational and mysterious. Teachers and community workers need to continue appling their Christ-centred efforts to the ideal of bringing about biblically-inspired transformation among the Lamba. The current syncretistic life-view of the Masaiti community, as described in section 6 above, should be eradicated in favour of a renewed, integrated and radically scriptural and hence Christ-centred life- and worldview. The Masaiti community should be guided to see reality as personal and relational. God created a universe of physical and spiritual dimensions, of seen and unseen worlds, and human beings should relate to both.

The discussion also supports the notion that life- and worldview transformation ought to be seen as a prerequisite for the developmental transformation of communities such as that of Masaiti. A transformational perspective is furthermore required for under-girding an effective and transformed educational strategy. The establishment of an education system based on a Christ-centred philosophy in and for the Masaiti community, seems crucial for achieving radical and total transformational development in this community. 


\section{List of references}

BATCHELOR, P. 1993. People in rural development. 2nd ed. London: Paternoster.

BUFFORD, R. 2007. Philosophical foundations for clinical supervision within a Christian worldview. Journal of psychology and Christianity, 26(4):293297.

CHIBUYE, W. 2010. Video recording on Koti ni Eden School. Masaiti, Zambia.

CHIKE, C. 2008. Proudly African, proudly Christian: the roots of Christology's in the African worldview. Black theology, 6(2):221-240.

COLSEN, C.W. 1999. How now shall we live? Wheaton: Tyndale.

CRAFFERT, P.F. 1997 The stuff world-views are made of. Scriptura, 61:193211.

CUNNINGHAM, J.D. \& FORTOSIS, A.C. 1987. Education in christian schools: a perspective and training model. Whittier: Association of Christian Schools International.

DIEN, D. 1997. Worldviews and morality: how do they intersect? Human development commentary, 40:345-349.

DOKE, C.M. 1931. The Lambas of Northern Rhodesia: a study of their customs and beliefs. London: Harrap.

DOKE, C.M. 1970. The Lamba of Northern Rhodesia. Connecticut: Negro University Press.

DREECKMEIER, T. 2005. Educative teaching. Pretoria: CcE Books.

EDGELL, M. 2007. Afro centric christian worldview and student spiritual development: tapping a global stream of knowledge. Journal of education and christian belief, 11(1):49-62.

ELS, C. 2009. Interviews held from 18-20 August 2009 in the Masaiti and Mpongwe district. (Unpublished.)

FCE see FOUNDATION OF CROSS-CULTURAL EDUCATION

FOUNDATION OF CROSS-CULTURAL EDUCATION. 2005. Responses of community workers to evaluate FCE's position in the community. Masaiti, Zambia.

FOUNDATION OF CROSS-CULTURAL EDUCATION COLLEGE. 2009. Summary of community student's assignments (2006-2009) on spiritual mindset research: transformational studies. Koti ni Eden, Masaiti. (Unpublished.)

FOWLER, S. 1987. Christian educational distinctives. Potchefstroom: Institute for Reformational Studies.

FOWLER, S. 2001. Contours of a transformational scholarship. (In Kok, J.H., ed. Marginal resistance. Sioux Center: Dordt College Press. p. 129-152.)

GRAY, J. 2009. Gray's anatomy. London: Lane.

HARRISON, L.E. 1985. Underdevelopment is a state of mind: the Latin American case. Lanham: University Press of America.

HIGHWAY CHRONICLES. 2005. Magazine of the Foundation for CrossCultural Education: 17, 24 Sept.

HOLMGREN, E.H. 1989. Signs and wonders in Africa: a biblical perspective in interaction with western missions, African independent churches and African traditional religion, with particular reference to Zambia. Lund: University Press of Lund. 
HOLMGREN, E.H., 2009. Interviews held from 18-20 August 2009 in the Masaiti and Mpongwe district. (Unpublished.)

KARECKI, M. 1998. Mission, ritual, worldview. Missionalia, 26(3):309-322, Nov.

KLAPWIJK, J. 1986. Antithesis, synthesis, and the idea of transformational philosophy. Philosophia reformata, 51:138-152.

KLAPWIJK, J. 1987. Reformational philosophy on the boundary between past and future. Philosophia reformata, 52:101-134.

KLAPWIJK, J., GRIFFIOEN, S. \& GROENEWOUD, G. 1991. Bringing into captivity every thought. New York: University Press of America.

LISATI, M.D. 2006. Report of the District Commissioner on Masaiti District Situational Analysis. (Unpublished.)

MECHIELSEN, J. 1980. No icing on the cake. Melbourne: Brookes-Hall Foundation.

MILLER, D.L. 1998. Discipling nations: the power of truth to transform cultures. 2nd ed. Washington: Ywam.

MILLER, D.L. \& BLIGNAUT, J. 2004. Let thy economic kingdom come. Lecture delivered at Hope for Africa Conference, 1 June 2004. Pretoria. (Unpublished.)

MILLER, D.L. \& SCOTT, A. 2005. Against all hope: hope for Africa - a Samaritan strategy for Africa. Montana Park: Africa Network Evangelism Task.

MUSHILI, Chief. 2009. Interviews held from 18-20 August 2009 in the Masaiti and Mpongwe district. (Unpublished.)

NASH, R.H. 1992. Worldviews in conflict. Grand Rapids: Zondervan.

NATURE PUBLISING GROUP. 2007. Patching together a worldview. Nature, 450(7171):761, Dec.

O'DONOVAN, W. 1992. Introduction to biblical Christianity from an African perspective. Ilorin: Nigerian Evangelical Fellowship.

PENSILU, L. 2009. Interviews held from 18-20 August 2009 in the Masaiti and Mpongwe district. (Unpublished.)

SCARBOROUGH, D. 1999. Thabo Mbeki's African renaissance: African spiritual powers vs. God's Word. http://wwwchristian.org.za/GDL/ newsletter/1999-May_June.htm Date of access: 4 Feb. 2008.

SILVOSO, E. 2007. Transformation. California: Regal Books.

VAN BRUMMELEN, H. 1988. Walking with God in the classroom. Burlington: Welch.

VAN DER WALT, B.J. 1991. A christian worldview and christian higher education for Africa. Potchefstroom: Institute for Reformational Studies.

VAN DER WALT, B.J. 2001. Shaping a radical biblical worldview. Word \& Action, 377:13-17.

VAN NIEKERK, A. 1993. Saam in Afrika. 4e dr. Kaapstad: Tafelberg.

VAN RHEENEN, G. 1991. Communicating Christ in animistic context. Grand Rapids: Baker.

VAN RHEENEN, G. 2003. Defining an animistic worldview. Ulaanbaator, Mongolia, on March 11, 2003. http://missionology.org/mongolianlecturers /animisticworldview.htm Date of access: 28 Jan. 2008.

WALSH, B.J \& MIDDLETON, J.R. 1984. The transforming vision. Illinois: InterVarsity.

WARD, A.R. 2005. Convertion in American society: exploring the practice of transformation. The journal of religion, 85(3):510, Jan. 
WOLTERSTORFF, N.P. 1980. Education for responsible action. Grand Rapids: CSI.

ZAMBIA. Department of Educational Statistics. 2007. Bulletin of the Ministry of Education: enrolment in all schools by gender and year. Version 6. Lusaka: Directorate Planning and Information.

\section{Key concepts:}

education, Christ-centred

life- and worldview

philosophy, personal

transformation

\section{Kernbegrippe:}

filosofie, persoonlike

lewens- en wêreldbeskouing

onderwys, Christus-gesentreerd

transformasie 